\title{
The Bamendjin Dam and Its Implications in the Upper Noun Valley, Northwest Cameroon
}

\author{
Richard Achia Mbih ${ }^{1}$, Stephen Koghan Ndzeidze ${ }^{2}$, Steven L. Driever ${ }^{1} \&$ Gilbert Fondze Bamboye ${ }^{3}$ \\ ${ }^{1}$ Department of Geosciences, University of Missouri-Kansas City, Kansas City, USA \\ ${ }^{2}$ Department of Rangeland Ecology and Management, and Integrated Plant Protection Center, Oregon State \\ University, Corvallis, USA \\ ${ }^{3}$ Department of Geography, University of Yaoundé I, Cameroon \\ Correspondence: Richard Achia Mbih, Department of Geosciences, University of Missouri-Kansas City, 5100 \\ Rockhill Road, Kansas City, MO 64110, USA. E-mail: ram989@mail.umkc.edu
}

Received: October 8, 2014 Accepted: October 23, 2014 Online Published: November 23, 2014

doi:10.5539/jsd.v7n6p123 URL: http://dx.doi.org/10.5539/jsd.v7n6p123

\begin{abstract}
Understanding the environmental consequences and socio-economic importance of dams is vital in assessing the effects of the Bamendjin dam in the development of agrarian communities in the Upper Noun Valley (UNV) in Northwest Cameroon. The Bamendjin dam drainage basin and its floodplain are endowed with abundant water resources and rich biodiversity, however, poverty is still a dominant factor that accounts for unsustainable management of natural resources by the majority of rural inhabitants in the area. The dam was created in 1975 and has since then exacerbated the environmental conditions and human problems of the region due to lack of flood control during rainy seasons, lost hope of improved navigation system, unclean drinking water sources, population growth, rising unemployment, deteriorating environmental health issues, resettlement problems and land use conflicts, especially farmer-herder conflicts. Despite hopes created by increased production of irrigated swamp rice, introduced to be a major cash crop, socio-economic and ecological problems have significantly reduced its chances of sustainable livelihood and poverty alleviation. Our study addresses the socio-economic implications of the Bamendjin dam as a rural development project to support rice production and other agro-pastoral activities and also examines related rural livelihood problems such as displacement of local communities and transformation of the landscape ecology. Stakeholders need to put in place an institutional framework for decision-making and policy implementation in order to realize the desired benefits of the dam and reverse its adverse effects on the UNV and its environs.
\end{abstract}

Keywords: Bamendjin dam, Upper Noun Valley, poverty, resettlement problems, sustainable development

\section{Introduction}

Dams are very important in socio-economic development and poverty alleviation worldwide through the generation of hydro-electric power, enhanced navigation systems, flood control, water storage, agro-pastoral production, fishing, tourism and conservation (Sukhan \& Sleigh, 2000; Brown et al., 2008; McNally et al., 2009). In 2010, hydropower generated from dams accounted for $20 \%$ of the world's electric power supply from over 45,000 large dams globally (International Energy Agency, 2012: 225; Tchouaha, nd). The World Commission on Dams (WCD) define large dams as being over $15 \mathrm{~m}$ high with a reservoir of about 3 million $\mathrm{m} .{ }^{3}$ Based on this criteria, about $50 \%$ of large dams are located in China and India, and in Africa, South Africa leads in dam construction (Manatunge et al., 2014; BWA, nd).

Cameroon has the second largest hydroelectricity potential in Africa after the Democratic Republic of the Congo, and hydropower provides about $95 \%$ of the energy for domestic and industrial production. Unfortunately, most of these industrial activities are limited in urban centers far from rural communities where the dams are constructed. These rural communities benefit very little from the dams, especially concerning electricity, population displacement, ecological changes and flooding of the rural landscape. Following the construction of the Bamendjin dam in the UNV in 1975, the surrounding displaced rural communities were faced with an acute lack of clean drinking water, electricity, roads and healthcare facilities (Lambi, 2001; Kometa \& Ebot, 2012). Although recently some villages have gained access to electricity, pipe-borne water and healthcare facilities, the 
majority of villages still lack electricity and proper healthcare. Most of them largely depend on rain water, springs, streams, rivers and other unclean sources for drinking water. Communities like Mufuo in Bamali, Mbissa Island in Bambalang, and some quarters in Bamunka, Babungo, Bamessing and Baba I, still rely on unclean water sources. The three main hydro-electric power stations of Edea, Songloulou and Lagdo are generated by dammed water from Mape, Mbakaou and Lagdo dams respectfully, and the Edea and Songloulou are reinforced by water from the Bamendjin and Lom-Panger dams during dry periods. The regions in which these dams are constructed have some of the poorest communities in Cameroon.

The feasibility study and subsequent construction of the Bamendjin reservoir started in 1971 to hold back the Noun River and its braided tributaries in the UNV floodplain commonly referred to as the Ndop floodplain. In 1975, the construction was completed across the Noun River. This was one of the first major rural development projects in West Cameroon during the second Five-Year Development Plan of 1966-1971, which was geared towards the economic development of Cameroon through industrial growth, rural electrification, water storage and agricultural projects. After its completion, the dam submerged more than $442 \mathrm{~km}^{2}$ of rural land in the Upper Noun Valley (Ngwa, 1985; Lambi, 2001; Lukong, 1990; Ndzeidze, 2008). Before the construction of the dam, the Noun River and its braided tributaries meandered in the Ndop plain forming an extensive wetland ecosystem characterized by fresh water marshes and seasonally flooded swamps (Mphoweh, 2007). The reservoir totally transformed the wetland ecology and rural landscape and increased land use conflicts within local communities in the UNV. The dam was constructed primarily to hold back water and increase the volume of water downstream at Edea during dry periods in order to generate hydroelectricity for the nation's power supply. Water volume regulation at Edea is through the opening and closing of the sluice gates of the Sanaga River, and this depends on the volume of the river at the hydropower station required to keep this facility operational. Sluice gates are opened during the dry season between the months of December and January and are closed during the first week of June, when the Sanaga River rises with the increase in rainfall intensity (Ngwa, 1985). At full capacity the water level is about $1,151 \mathrm{~m}$ high and floods an area of over $442 \mathrm{~km}^{2}$, far beyond the expected limit of $333 \mathrm{~km}^{2}$ suggested by the project's feasibility study. At this point of full capacity, the dam can flood all the lowlands and valleys including all the 13 villages within the Ndop floodplain. Water volume then is about $1,875,500 \mathrm{~mm}^{3}$. At this level, dam officials closely watch the lake and any further increase in water volume is considered excess and the sluice gates are opened to regulate its capacity (Ngwa, 1985; Lukong 1990). Unfortunately, in this situation, the negative effects of the dam are unbearable in the UNV for some local communities. This paper therefore aims at evaluating the impacts of the Bamendjin dam by examining the socio-economic and environmental implications of the dam on rural livelihoods in local communities in the UNV.

\section{Material and Methods}

The UNV commonly known as the Ndop plain is an important drainage basin on the Noun River within the Western Highlands of Cameroon (figure 1). It is predominantly a seasonally flooded wetland characterized by rich alluvial soils and aquatic biodiversity, which has attracted diverse agro-pastoral development. The floodplain is rich with many socio-cultural and economic activities that have initiated, modernized and intensified the traditional agricultural system for better yields and rural development. Constructed in the Bamendjin village of Galim Sub-division, the dam mostly affects the areas of Foumbot, Foumban, Galim and Ndop in the Bamboutous, Noun and Ngoketunjia Divisions in the West and Northwest Regions, respectively. All these regions are located within the Noun River drainage basin. Ndop has the highest number of communities affected by the dam because of its low-lying nature, and this is why the UNV is often referred to as the Ndop flood plain. 

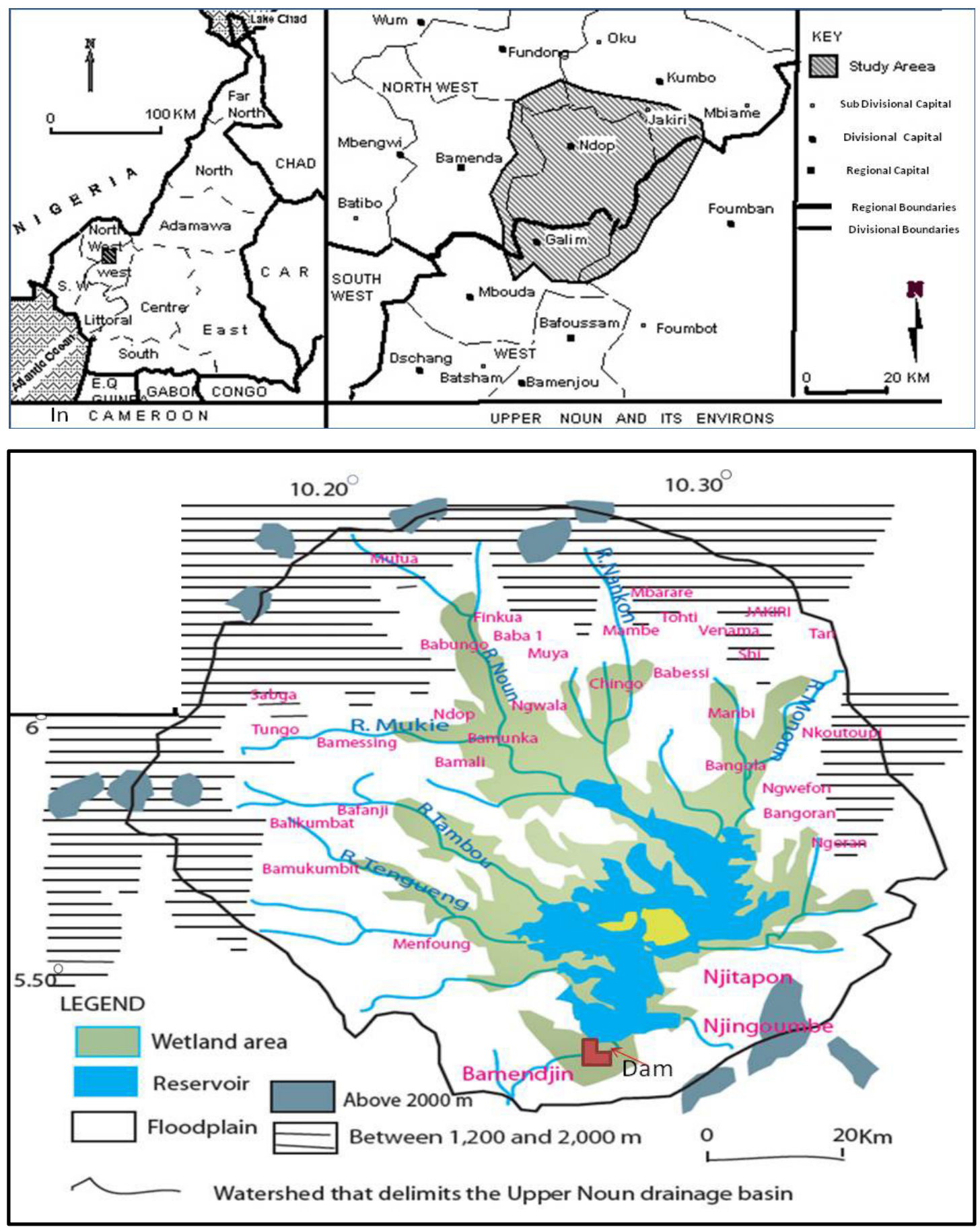

Figure 1. The Bamendjin dam in the Upper Noun Valley and its surrounding watersheds

Source: adapted from Ndzeidze, 2008

Data for this study were collected during the dry and rainy seasons from 2009 to 2013 for a total of 12 months. Primary interviews and discussions were conducted on households, focus groups and individuals in the 13 villages within the drainage basin (Bamunka, Bamali, Babessi, Baba I, Bambalang, Bamessing, Babungo, Bafanji, Balikumbat, Bamukumbit, Bangoland, Baligham and Baligansin) to investigate the basic problems that originated from the dam. Agro-pastoral communities in the upper drainage basin of the Noun River like Sabga in Mezam Division and Jakiri, Oku and Ber villages in Bui Division were also visited to obtain primary information. Target resource persons were adult members of heads of households that depend mainly on farming, grazing and fishing activities, and adult members of communities whose land was largely covered by dam waters. 
Such villages include Babessi, Bamunka, Babungo, Bamali, and Bambalang, where almost half of the villages is submerged creating small Islands like Mbissa Island. Secondary data were obtained from existing relevant literature, archives of the Senior Divisional Office (SDO) of Ngoketunjia Division, various ministerial departments dealing with agro-pastoral activities, and agricultural development agencies like the Upper Noun Valley Development Authority (UNVDA). Information gathered from these sources include agro-pastoral and population statistics, the Bamendjin dam project files, data on land use conflicts and the socio-economic and environmental effects of the reservoir during its early period of creation, and the most affected communities in the drainage basin.

\section{The Effects of the Bamendjin Dam in the UNV and Its Environs}

The creation of the Bamendjin dam and its reservoir in 1975 remains controversial in the minds of many rural inhabitants in the UNV. The dam transformed the rural agro-pastoral landscape and settled land in the region. Some of the immediate effects of the dam were the submergence of the gallery forest, raffia bushes and destruction of other vegetation, all of which led to the diminution of cultivable land and pasture. Subsequently, many local communities, whose land was covered by water, were displaced. Community sources of potable water such as springs and wells were flooded. Road infrastructures were also inundated, making transportation within the UNV floodplain difficult. Prior to the Bamendjin dam, the plain served as an important transhumance zone in the Western Grassfields of Cameroon. After the dam construction, significant seasonal grazing areas for transhumance were lost to reservoir waters, depriving more than 40,000 heads of cattle that often migrate into the region from surrounding plateaus during dry periods for wetland pasture (Ngwa, 1985).

Some 307,757 people in the UNV area in the Northwest and West Regions and more than a thousand local inhabitants were involuntarily displaced from their original settlements due to the destruction of their properties. All 13 villages in the Ndop plain were affected by the reservoir. According to Ngwa (1985), about 1,019 people from 11 communities migrated immediately after the completion of the dam in 1975 (see Table 1). Project officials considered compensation for those displaced that also took into account the property destroyed.

Table 1. Some communities affected by the Bamendjin dam water and property destroyed

\begin{tabular}{ccccc}
\hline Region & Villages & $\begin{array}{c}\text { No. of displaced } \\
\text { people }\end{array}$ & $\begin{array}{c}\text { No. of houses } \\
\text { affected }\end{array}$ & No. of coffee trees submerged \\
\hline \multirow{6}{*}{ Northwest } & Bambalang & 402 & 133 & - \\
& Babessi & 95 & - & - \\
& Bafanji & 22 & - & 1,945 \\
& Bamunka & 46 & - & - \\
& Bangolan & 58 & 3 & 1,896 \\
& Baba I & 5 & - & - \\
& Balikumbat & 14 & 14 & - \\
& Bamendjin & 125 & 127 & 33,128 \\
West & Nkoumangha & 108 & 26 & 58,801 \\
& Njitapon & 89 & 83 & 79,762 \\
\multirow{2}{*}{ Total } & Njigoumbe & 55 & 12 & $\mathbf{1 8 1 , 1 3 7}$ \\
\hline
\end{tabular}

Source: Ngwa (1985)

The uprooted populations were in four sub-divisions and the total number that was eventually displaced was about 8,582 people (table 2). The people considered for compensation were those whose houses and crops were destroyed by flood, while the majority, which relocated for fear of subsequent destruction of property, was never considered. Lack of transportation facilities, sufficient drinking-water, schools for children, and various social amenities as well as environmental insecurity led to many people leaving the area, and they never were compensated. Even those who qualified for compensation were sometimes not reimbursed, while other communities were under-compensated because of the corrupt practices of the local administrative officials 
responsible for the payments. The long, tedious bureaucratic procedures of getting compensation for lost properties disappointed the majority of the local population, many of whom gave up and still express extreme disapproval of the Bamendjin dam project.

Table 2. Number of displaced persons and houses submerged per sub-division in the UNV

\begin{tabular}{ccccc}
\hline Sub-divisions & $\begin{array}{c}\text { Population (Pop. census } \\
\text { 1976) }\end{array}$ & $\begin{array}{c}\text { No. of displaced } \\
\text { persons }\end{array}$ & $\begin{array}{c}\text { \% of displaced } \\
\text { population }\end{array}$ & $\begin{array}{c}\text { No. of houses } \\
\text { submerged }\end{array}$ \\
\hline Foumban & 68,526 & 428 & 0.62 & 101 \\
Foumbot & 129,003 & 250 & 0.19 & 50 \\
Galim & 19,764 & 157 & 0.49 & 160 \\
Ndop & 92,464 & 7,747 & 8.38 & 2,867 \\
Total & 307,757 & 8,582 & 2.78 & 3,178 \\
\hline
\end{tabular}

Source: Lukong, 1990

The situation in some communities was all the more serious because the reservoir took them by surprise. These communities had little information about the construction of the dam and underestimated its effects. This lack of awareness, according to most villagers, was a deliberate result of project officials not wanting local communities to get involved in the decision-making of the project. The few community leaders involved were made to accept all decisions taken by the project officials. The hidden agenda not to publicize much about the project for fear of local reactions against it led to limited public awareness and a few pro forma meetings organized by project officials to reassure the local population about the dam. Villagers were not given the opportunity to express their opinions, and major decisions were taken without the concerns of the few villagers chosen to represent their people. Many individuals and communities saw only water coming from an unknown source and were forced to move. Others escaped to places outside the region and hoped to return when the flood waters had receded, but soon realized they would never return home. Some of those who had no idea about the project attributed the dam water to witchcraft, blaming their ancestors and gods of their communities for such spiritual calamity. According to feasibility studies carried out by Energie Electrique du Cameroun (Cameroon Electrical Energy) in 1971, the construction of the dam was identified as a potential environmental hazard capable of causing serious socio-economic problems, including the destruction of settlements and the natural ecology of the Region (Ngwa, 1985). But the feasibility study submitted by this energy corporation to the Cameroon Ministry of Finance that sponsored the project was never taken into consideration and the dam construction began in 1972. The feasibility study was to evaluate the intensity of the damage and to determine the amount of compensation for resettlement. Compensation paid to the local population for property damage was classified into two categories. In the first were individuals and households whose houses, crop farms and coffee farms were destroyed by the lake water. These compensations were rated from 1 to $50 \%$ and 50 to $100 \%$, which could be explained only by the evaluating team but remained unclear to the natives. The second category was for rural infrastructures destroyed, such as road networks, schools, drinking water outlets, market squares and other public places.

\section{Socio-economic and Environmental Implications of the Bamendjin Dam}

Dams change landscapes and create environmental risks with impacts that can hardly be reversed (Manatunge et al., 2014). Such negative outcomes of dams have been responsible for some of the debates against the erection of large dams as their role in sustainable development is questionable to stakeholders and researchers, especially when considering the dangers of global climate change and the rapid growth of population that hampers most measures supporting human sustainability (Manatunge et al., 2014; Cernea, 2004). With very little impact assessment, the Bamendjin dam was built primarily to create a reservoir for national hydro-electric power. Some researchers, development agencies and local inhabitants have questioned the creation of the Noun River dam given its significant negative socio-economic and ecological impacts on the UNV and its surrounding areas, especially the involuntary human resettlement (Ngwa, 1985; Lukong, 1990; Lambi, 1999: 2001; Ndzeidze, 2008).

Following the dam construction, environmental and land security has been a major issue, as evidenced by farmer-herder and herder-herder conflicts over land and inter-tribal wars over landuse resources. The Noun River watershed has been highly degraded upstream by displaced farmers carrying out intensive agro-pastoral activities, 
deforestation causing severe soil erosion, and environmental pollution (Lambi, 2001; Kometa and Ebot, 2012; Ngwa 2003). This situation is compounded by a drop in the water table and insufficient potable spring water from nearby watersheds. The water table of the floodplain upstream from the dam rose due to reservoir waters making wells and spring water unsafe for human consumption. Some of the standing water, slow flowing streams and the Bamendjin Lake itself have become potential breeding grounds for vectors of waterborne diseases such as malaria, cholera, typhoid and bilharzia. There is a common saying that originated among the local population in the area after the construction of the dam that "there is abundant water supply in Ndop, but no water to drink."

These issues have raised serious environmental health concerns because more than $80 \%$ of the villages in UNV do not have clean drinking-water sources and depend solely on shallow springs, storm water, wells, rivers and streams for domestic water sources. This concern is compounded by the increased risk and high rates of malaria (Demgne 2001; Ngwa 2003). Cholera epidemics also have been common due to poor drinking water quality. The cholera outbreak in Babungo village in 1996-1997 was attributed to contaminated water downstream caused by the used of toxic chemicals upstream by herders treating animals for ecto-parasites (Kometa \& Ebot, 2012). Climate change, population growth and land scarcity have minimized the degree of success for most measures to reduce the spread of these infectious diseases. The intensive use of chemical fertilizers and herbicides largely account for the significant drop in the number of fish in the rivers and in the Bamendjin reservoir. Fishing was one of the main economic activities following the erection of the dam and benefited the local population as a major protein source for communities around Babungo, Bangolan, Bambalang, Bamali, Bamunka, Babessi and Baba I.

Human adaptation to the many consequences of the Bamendjin dam has been very difficult. Facing the new challenges that accompany displacement, families in new locations had to deal with socio-cultural, economic hardship and psychological trauma. Most families in the area have remained poor and vulnerable to diseases with little hope for a better future. Before the creation of the dam, most of the villages in the area were located in the plain characterized by flat and gentle slopes (1-6\%) with fertile alluvial soils that favored year-round agro-pastoral activities. The moderately steep slopes (7-25\%) characterized by granitic soils and undulating topography also favored human settlement and agro-pastoral activities (Kometa \& Ebot, 2012). After the dam most villages were forced to resettle on land with higher relief, about 25 to $55 \%$ slopes, and basaltic and trachytic soils that supported only moderate agro-pastoral activities. Such shallow soils in highlands favor mostly livestock production and grazing by local inhabitants. Food insecurity is a common problem and transportation from farm to market through the high relief areas, especially during the rainy season on unpaved roads, is very difficult, making the transportation of agricultural products to market very expensive and the market prices of food crops higher.

Loss of cultural-heritage assets to flood waters and displacement has had a very significant effect on the indigenous customs and lives of the people. As in any part of African rural communities, the people have strong attachments to their birth places and ancestral land. Displacement and resettlement mean lots of sacrifices and giving up what will never be regained to a reservoir. Many families practice ancestral worship and believe that land is for livelihood and communication with their ancestors and gods in times of need such as during famine, epidemics, prolonged droughts, and planting and harvesting seasons. They also consult their gods during inter-tribal conflicts for victory. Unfortunately, some of these sacred places and shrines were covered by water, including their ancestral burial ground and family properties. During our field survey interviews, some of the traditional leaders argued that they considered the destruction of some of their heritage shrines by reservoir water 'serious calamities' because their gods could no longer be appeased. They still believe that the flooding and subsequent displacement were vengeance from the gods and that, if the gods were further annoyed, they could unleash death, famine, epidemics, droughts and many other problems. Strong attachment to their ancestral land made some communities remain in place despite their isolation and possible destruction. Inhabitants of Mbissa Island in Bambalang village decided to stay in place though surrounded by water and cut-off from the mainland Bambalang village. Transportation to this Island to date is by boats and canoes.

\section{Importance of the Bamendjin Dam in the UNV}

Apart from being an important source of hydro-electric power in Cameroon, the dam is also a major touristic site in the UNV. Most tourists visiting Northwest of Cameroon stop at the dam and admire the traditional fishing techniques with the use of baskets, barriers, hooks and other forms of traditional fish traps. The wide view of the lake, surrounded by extensive wetland habitats and patches of gallery tropical forest intermixed with swamp forest, is an interesting scenic site that attracts more than a thousand visitors annually for either vacations or research. Water transportation between the Northwest and West regions of Cameroon has been facilitated by the 
reservoir. It takes about 30 minutes to an hour by boat from the village of Bamunka or Bambalang in the Northwest to Foumban villages in the West Region of Cameroon.

Fishing is an important economic activity and a source of protein in the villages of Bamunka and Bambalang, where it supports the livelihoods of most families. Fishing is the main holiday activity for most youth in the UNV flood plain, especially in Bambalang village. Although not affordable to all, the reservoir waters are used by Cameroon Water Corporation (Cam-Water) to supply drinking water to the few middle class families and to limited public taps, mostly in urban centers.

Irrigated swamp rice became a major rationale of the Cameroon government that the dam and reservoir benefited local communities in the UNV and the Northwest Region as a whole. Rice cultivation had been the main cash crop in the Region after the drop in coffee production due to falling market prices in the 1980s. Rice cultivation provides seasonal employment to the local population, including the youth, during growing seasons and holidays Villagers from other parts of the Northwest and West regions also migrate to the UNV for seasonal employment during this cultivation season (June to September). Rice production in the region is under the coordination of the Upper Noun Valley Development Authority (UNVDA), a corporation created by the state in 1971 to manage and develop the cultivation of rice and other food crops in the UNV area. Ndop, the main urban center in the UNV, is often very populated during cultivation season by seasonal migrants from neighboring communities in search of temporary agricultural jobs on the farms, with some of these jobs provided by the UNVDA Corporate Headquarters in Ndop. Most migrants often come from Kom, Mbessa, Bum in Boyo Division, and Oku, Kumbo and Jakiri in Bui Division, Ndu, Nkambe in Donga-Mantung and Babanki in Mezam Divisions. This migration pattern has greatly contributed to the growth of Ndop town as a major cosmopolitan community since the $1980 \mathrm{~s}$ with all forms of social ills such as drug trafficking, prostitution, HIV/AIDs, robbery, cultism, homicides and drunkenness among local inhabitants. Ndop (the city) has an HIV/AIDs prevalence rate of 9.4\% and is considered one of the region with the highest prevalent rate in Northwest Cameroon, with a regional rate of $8.7 \%$, with women being more infected than men at the rates of $11.9 \%$ and $5.2 \%$, respectively (Behrendt \& Mbaye, 2008). These high rates of HIV result from prostitution and insufficient sex education.

The dam greatly facilitated the expansion of the UNVDA created as part of the Second Five-Year Economic Development Plan of 1966-1971. The state created the UNVDA to exploit the favorable ecological conditions of the floodplain for boosting rice cultivation and employment in the region. The dam waters enabled the expansion and construction of irrigation canals through land development by the UNVDA, which helped in meeting the national target of about 34,000 tons of annual rice production for consumption. To facilitate the expansion process, the Development Authority created farm to market routes between the rice fields and settlements within the floodplain, provided rice seed and fertilizers to farmers, and sent out field extension workers to encourage them to increase their farm sizes and production. Between 1971 to 2012, the total surface area of rice production rose from 33 ha to more than 3000 ha with more than 6000 farmers involved in its cultivation in the Ndop plain and its environs (Ngwa, 2003; Ndzeidze, 2008; UNVDA, 2012). The increased rice production raised the standards of living of the rice farmers, and the economy of their communities, in the UNV as farmers received about 188 million Central African CFA francs (US\$376,000) annually from rice sales to UNVDA.

\section{Discussion}

Dams are typical examples of economic development projects that can be very detrimental to livelihoods and sustainability, especially if not well conceived and implemented. Such development projects in many cases have contributed to livelihood impoverishment instead of alleviating poverty and promoting growth. Cernea (2004) puts it as a situation of fighting "new poverty" along with "old poverty." According to him, the fight against poverty should be aimed at reducing existing causes and preventing new impoverishing processes resulting from projects like dam construction. In the UNV, around the Bamendjin dam, about $80 \%$ of the local population lived below poverty line of 232,547 CFA francs in 2001 and 269,443 CFA francs $(\$ 1=500$ CFAF) in 2007 according to the Cameroon Ministry of Finance (IMF, 2010). This poverty level in the region indicates no change since the creation of the dam in 1975 or even an increase due to inflation and increasing costs of living, compounded by degrading environmental conditions. Questions are still raised in heated debates concerning the fairness of the UNV rural inhabitants still suffering the effects of the reservoir. If the welfare of local inhabitants were considered, the state and project officials would have included local community members in the major decision-making processes of the Bamendjin dam project.

Environmental justice, equity, governance and economic development characterize the global debate on dam construction today. Although dams are a source of economic development through irrigation, hydro-electric power supply, water storage, flood control and a means of natural conservation, they alter human landscapes and the use 
of natural resources, causing human displacement and reallocation of benefits from local riparian users to new group of beneficiaries in cities and urban centers (Bottero, 2013: 179). The construction of the Bamendjin dam is a clear case of environmental injustice to the people of the UNV whose resources have been destroyed by the dam water for hydro-electricity that benefited mostly the nation's urban centers. Most of the rural communities in the UNV do not have electricity, health facilities, enough agricultural space and clean drinking-water sources. Their natural springs, farmlands were covered by water for the generation of electricity, and that water also increases the risk of malaria and waterborne diseases in the area. Most of the inhabitants are poor and cannot afford to pay water and electricity bills, not to mention being able to connect tap water and electricity to their homes. Those who are able to afford running water and electricity suffer from extended water-cuts and power blackouts most of the time. Some of the power cuts in rural areas are due to rationing, which is often in favor of urban centers because of industrial development, businesses and political reasons. There are often extended periods without light in the UNV area that ranges from a few days to weeks. It is also very common for public taps to go for many months and years without flowing. Presently, there are no public taps in Ndop. The poor local population depends permanently on natural sources of water. The villages of Bambalang and Bamendjin, whose land was extensively covered by water and fishing became an important source of economic activity and employment, have suffered greatly in recent years due to a rapid decline of the lake's fish population caused by environmental pollution resulting from agricultural intensification upstream. Other local inhabitants argued that the dam enabled the expansion of irrigated rice fields to their farmlands, thereby transforming their family land into public properties as most of the floodplain is being developed into irrigated rice fields by the state through the Upper Noun Valley Development Authority (UNVDA) responsible for the management of rice production in the region.

\section{Conclusion}

Forced resettlement and its subsequent socio-economic impacts are common problems resulting from the building of dams. Displacement of population always results in material losses, under-compensation and social disruption of local communities. These complications are always underestimated in feasibility studies and during the early stages of the project. The Bamendjin dam immediately affected over 307,757 people, forcefully displacing about 8,582 inhabitants as it submerged 3,178 houses in the UNV. The adversely affected population increased over the years despite the development of rice production and other agricultural activities like the raising of corn and groundnuts. The majority of the population still lacked clean drinking water, electricity and agricultural land. The World Commission on Dams estimates that dam-triggered human displacement globally ranges between 40 to 80 million people, and researchers have estimated that most of the over 50 to 55 million people displaced in India in 50 years of development were uprooted by dam construction and that the displacement of about 45 million inhabitants of China also was caused mostly by dams (Cernea, 2004). Despite the many negative human and environmental effects of hydropower dams in the world, dam promoters and development agencies cannot stop constructing them due to their advantages over other sources of energy like nuclear power, which generates nuclear waste and leaks that are detrimental to the environment and human health. Hydropower energy is clean and relatively inexpensive, and its generation can be regulated to meet changing demands for electricity, a flexibility not associated with wind and solar energies. If well planned, dams can be relatively environmentally benign, and local populations can benefit from them through conservation and sustainable development. The Bamendjin dam, however, needs serious institutional reforms implemented for the benefit of stakeholders, with the needs of local inhabitants addressed first and then the natural ecology of the UNV and that of the nation as a whole considered next. The situation of the Bamendjin dam in the UNV can be improved through a community action plan that includes the proper investigation of different elevations and aquifers for boreholes that will provide clean, free drinking water for the communities and the digging of irrigation canals within lowland areas around farmlands that will store and supply water to farmers during dry periods.

\section{Acknowledgement}

We thank the late Professor Emmanuel N. Ngwa of the University of Yaoundé I, Cameroon, for his material support and guidance during our fieldwork in Northwest Cameroon.

\section{References}

Behrendt, C., \& Mbaye, S. M. (2008). The psychosocial impact of parental loss and orphanhood on children in an area of high HIV prevalence: A cross section study in the North West Region of Cameroon. Dakar: Project Report sponsored by USAID, AWARE, FHI and Plan International.

Borehole Water Association of Southern Africa (BWA). Nd. Dams in South Africa. Borehole Water Journal, 83. Retrieved August 9, 2014, from http://www.bwa.co.za

Bottero, M. (2013). Sustainability assessment of large dams: the case of a hydropower plant in the Bulgaria. 
Management of Environmental Quality, 24(2), 178-198. http://dx.doi.org/10.1108/14777831311303074

Brown, P., Magee, D., \& Xu, Y. (2008). Socioeconomic vulnerability in China's hydropower development. China Economic Review, 19(4), 614-627. http://dx.doi.org/10.1016/j.chieco.2008.06.002

Cernea, M. (1999). Why economic analysis is essential to resettlement: A sociologist's view. In M. Cernea (Ed.), The economics of involuntary resettlement: questions and challenges (pp. 5-49). Washington, D. C.: The World Bank. http://dx.doi.org/10.1596/0-8213-3798-X

Cernea, M. (2000). Risks, safeguards and reconstruction: A model for population displacement and resettlement. In M. Cernea (Ed.), Risks and reconstruction: Experiences of resettlers and refugees (pp. 11-55). Washington, D. C.: The World Bank. http://dx.doi.org/10.1596/0-8213-4444-7

Cernea, M. (2004). Social impacts and social risks in hydropower programs: Preemptive planning and counter-risk measures. In Proceedings of the United Nations Symposium on Hydropower and Sustainable Development Beijing, China, 27-29 October. Retrieved November 16, 2014, from http://www.un.org/esa/sustdev/sdissues/energy/op/hydro_cernea_social\%20impacts_backgroundpaper.pdf

Demgne, H. (2001). Sustainable plan to roll back malaria in Cameroon via education, use of insecticides, impregnated bednets and environmental sanitation. Unpublished Thesis. Lund University, Sweden.

International Energy Agency. (2012). World energy outlook: Renewable energy outlook. Retrieved July 7, 2014, from http://www.worldenergyoutlook.org

International Monetary Fund (IMF). (2010). Cameroon: poverty reduction strategy paper. IMF Country Report No. 10/257. Retrieved from http://www.imf.org

Kometa, S., \& Ebot, M. (2012). Watershed degradation in the Bamendjin area of the North West Region of Cameroon and its implication for development. Journal of Sustainable Development, 5(9), 75-84. http://dx.doi.org/10.5539/jsd.v5n9p75

Lambi, C. M. (1999). The Bamendjin Dam of the Upper Noun Valley of Cameroon: No human paradise. Readings in Environmental Education Project. University of Stracthcleydes, Glassgow-Scotland.

Lambi, C. M. (2001). Environmental constraints and indigenous agricultural intensification in Ndop plain (Upper Noun Valley of Cameroon). In Lambi C. M., \& Eze B. E. (Eds.), Readings in Geography (pp. 179-190). Bamenda: Unique Printers.

Lukong, J. N. (1990). The resettlement process in the Upper Noun Valley (UNV). Master's Thesis. University of Yaoundé.

Manatunge, J., Nakayama, M., \& Priyadarshana, T. (2014). Environmental and social impacts of reservoirs: issues and mitigation. Sample chapters, UNESCO Encyclopedia of Life Support Systems (EOLSS), 1. Retrieved July 28, 2014, from http://www.eolss.net/Sample-Chapters/C12/E1-06-02-06.pdf

McNally, A., Magee, D., \& Wold A. T. (2009). Hydropower and sustainability: Resilience and vulnerability in China's powersheds. Journal of Environmental Management, 90, 286-293. http://dx.doi.org/10.1016/j.jenvman.2008.07.029

Mphoweh, J. N. (2007). The degradation of wetlands and its socio-economic and environmental implications in Ndop Central Sub-division, North West Province, Cameroon. Unpublished Master's Thesis, University of Yaoundé I, Cameroon.

Ndzeidze, S. K. (2008). Detecting changes in a wetland: Using multi-spectral and temporal Landsat in the Upper Noun Valley Drainage Basin-Cameroon. Unpublished Thesis. Oregon State University.

Ngwa, C. A. (2003). Development authorities as agents of socio-economic change: An historical assessment of the Upper Noun Valley Development Authority (UNVDA) in the Ndop Region of Cameroon, 1970-1995. Nordic Journal of African Studies, 12(12), 220-237.

Ngwa, E. N. (1985). Impact of agricultural innovation agencies in a rural environment: An example of the Upper Noun drainage basin. Unpublished dissertation. University of Yaoundé, Cameroon.

Nkwemoh, C. (1999). The impact of agro-pastoral activities on the physical environment of the Mezam-Ngoketunjia area. Unpublished Thesis, University of Yaoundé I, Cameroon.

Nkwi, W. G. (2011). Sons and daughters of the soil: Land and boundary conflicts in the North West Cameroon, 1955-2005. Bamenda: Langaa Research \& Publishing Common Initiative Group.

Sukhan, J. and Sleigh, A. (2000). Resettlement for China's Three Gorges Dam: Socio-economic impact and 
institutional tensions. Communist and Post-Communist Studies, 332(2), 223-241.

Tchouaha, S. T. (n. d.). Hydropower in Cameroon. BA Thesis. University of Gävle. Retrieved July 7, 2014, from http://www.diva-portal.org/smash/get/diva2:477398/FULLTEXT01.pdf

\section{Copyrights}

Copyright for this article is retained by the author(s), with first publication rights granted to the journal.

This is an open-access article distributed under the terms and conditions of the Creative Commons Attribution license (http://creativecommons.org/licenses/by/3.0/). 